\title{
Innovative changes in Quantity Surveying Practice through BIM, Big Data, Artificial Intelligence and Machine Learning
}

\author{
Rafiu Dimeji Seidu, Bert Ediale Young ${ }^{2}$, Jamie Clack ${ }^{3}$, Zulfikar Adamu ${ }^{4}$ and Hebert \\ Robinson ${ }^{5}$.
}

1, 2, 4 and 5: School of the Built Environment and Architecture, London South Bank University, London, SE1 0AA, United Kingdom

3. PSE Associates, 83 Queens Road, Brighton, BN1 3XE, United Kingdom

\begin{abstract}
Like many construction industry professions, quantity surveying (QS) has been around for many years and has undergone many changes to reflect developments within the wider industry and society. The proliferation of computers into the design process starting from the 1980's leading up to the rise of Building Information Modelling has particularly led to significant changes in the design and construction landscape. In the UK for instance, the proliferation of BIM and possible demise of traditional Bill of Quantities, with the concurrent rise of smart buildings/cities with exploitation of Big Data (BD), artificial intelligence (AI) and Machine Learning (ML). It implies that $\mathrm{QS}$ practices need to reflect on emerging products and services that can promote construction quality and productivity as well as their own professional development. With the decline of traditional QS roles and increased focus on speed of construction, there may be opportunities for different roles for quantity surveyors when dealing with data-driven needs of advanced clients such as BIM managers and Project managers. Additionally, there is need to improve the market value for traditional QS practices when dealing with less innovative clients with less time constraints, which inadvertently contributes to a skills gap which will allow practices to charge more for the traditional services. This study is an exploratory research based on secondary data, which is aim at understanding BIM adoption and related technical advancements that represent innovative and emerging roles for QS professionals to meet the growing demands in the industry. The findings will ignite and support the need for changes in practice, professional education as well as attitudinal behaviour required toward the UK's Construction 2025 goals.
\end{abstract}

Keywords: Quantity Surveying, Building Information Model, Innovation, Productivities, Construction. 


\subsection{Introduction}

The innovation brought about by Building information modelling (BIM) adoption \& compliance affects Quantity Surveying (QS) practices nowadays (BIM Ireland, 2016), and the future of the profession is at an important crossroad. Innovation in UK construction industry is nothing new, but the UK seems to lag behind advances by the rest of European in terms of BIM (Bimplus, 2019). However, with the UK government mandating BIM for all their projects (GOV.UK, 2019) it is plausible that this could this lead the way for others clients to do the same. This is because BIM is demonstrating the capacity to change not only contemporary QS work practices but potentially the entire UK construction industry (Fung et al, 2014).

UK construction is a crucial part of the economy and is still incredibly busy despite a lack in growth. "Wider construction accounts for nearly 7\% of UK's value added, of which construction related products and services account for about 1\% each and contracting accounts for about $4.7 \%$. Some 3 million jobs are based in construction, 10\% of total UK's Employment" (HMGOV.UK, 2013). There is also a large supply chain within the construction industry, which tends to remain within the UK, it is around $f_{12} 12$ billion of the consumption (HMGOV.UK, 2013) and directly linked to the country's GDP. Given the capital intensive nature of construction projects and the impact they have on a country's economy; it is not far-fetched to argue that cost estimators are an essential part of the construction industry. Consequently, advances in the industry such as in BIM adoption will affect the role of the quantity surveyor perhaps in more ways than previously understood. One reason being that the low profit margins typical of construction projects, for example as reported by The Construction Index (2017) the top 100 contractors in the UK earned a pre-tax profit of around 1.5\% in 2017. Given such low profits for large contractors, it is plausible to imagine that Small and Medium Scale (SME) organisations, which form the bulk of the supply chain, are operating at even lower profit margins. Consequently, opportunities to extract value and profitability from capital investments will rely on the professional astuteness and the ability to exploit new technologies for value realisation by professionals such as QS whose role is primarily costing.

The quantity surveying role within the construction industry has been around for many years and like most professions had to change with the times, most noticeably in 1980s with the introduction of computers and the possible demise of Bill of Quantities (Cartlidge, 2013) and as a result, QS practices started to develop different services (Cartlidge, 2013) to provide new opportunities for young quantity surveyors with the introductions of technologies which will put quantity surveyors at the forefront once again (Sawhney, 2016). With the decline of traditional QS roles and more focus on speed of construction (Cartlidge, 2013) it is vital that the profession evolves as there may be emerging opportunities for different roles for quantity surveyors when dealing with experienced clients such as; BIM managers and Project managers with a quantity surveying background (Sawhney, 2016). This may create a new market for the traditional QS practices when dealing with less innovative clients with less time constraints and higher cost pressures according to Keelagher, 2017), leading to a skills gap which may permit practices to demand a higher fee structure or band for more traditional services. This study is therefore an exploration into how BIM and related digital technologies such as Big Data (BD), Artificial Intelligence (AI) and Machine Learning (ML) are going to affect traditional QS responsibilities and how they might going change the QS practice as a whole. 


\subsection{Literature Review}

\subsection{Building Information Modelling Adoption in UK.}

Building information modelling (BIM), is a 3D model-based process (Autodesk, 2019), that provides professionals information and tools to efficiently plan, design, construct and manage buildings and structures. It allows design clashes to be detected and cost scheduling correction before construction, saving both time and money in the process (Kunz and Gilligan, 2007; Azhar, 2011). It is an intelligent model-based system, that gives architecture, engineering and construction (AEC) professionals the insight and tools to more efficiently plan, design, construct, and manage buildings and infrastructure (Autodesk, 2019). In addition, as an IT enabled approach it involves applying and maintaining an integral digital representation of all building information for different phases of the project life cycle in the form of a data repository ( $\mathrm{Gu} \&$ London, 2010). These definitions put all the emphasis on the technology and do not recognise the collaborative working that is required for BIM projects.

There is some argument over actual definition of BIM and the abbreviation should be Building information management (RIBA, 2012). This indicates alternative views that BIM is not all about technological innovations as the management is crucial (Pittard \& Sell, 2017). This implies a technological focus, where the focus should be on the collaborative working that BIM creates. In other words, BIM “essentially, combines technology with new working practices to improve the quality of the delivered product and also improve the reliability, timeliness and consistency of the process to create, control and amend the information" (Pittard and Sell, 2017). This means the right processes and management need to be in place alongside the technology for successful BIM working.

BIM Levels are measured in terms of maturity, relating to the progressively moving construction to full collaborative working within the range of Levels 0 to 3 (BIM Industry Working Group. (2011), with basic 2D CAD mostly considered as Level 0 as pre-BIM status. Level 1 refers to the migration from $2 \mathrm{D}$ to $3 \mathrm{D}$ and object-based modelling and documentation, Level 2 progresses from modelling to collaboration and interoperability whist Level 3 is the transition from collaboration to integration (Fig 1). It reflects the real underlying BIM philosophy including business intelligence, lean construction principles, green policies and whole lifecycle costing (Khosrowshahi \& Arayici, 2012); and studies (RIBA, 2012 and Dakhill, et al, 2019) have considered Stage 3 as the "Holy Grail" for a digitally built Britain. 


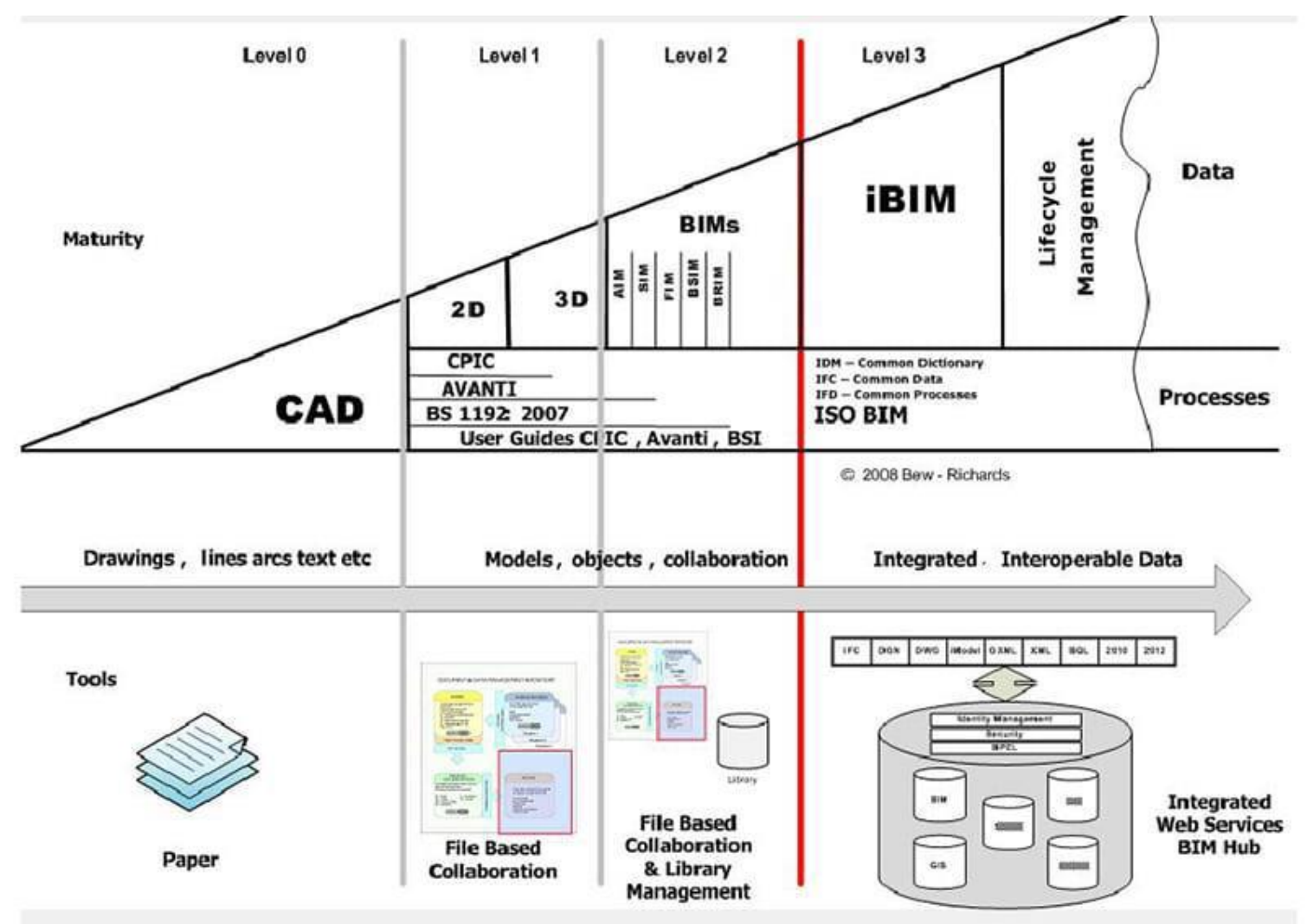

Figure 1 - BIM maturity model (BIM Industry Working Group, 2011).

In simple terms, BIM represents a paperless process (Jiang, 2011), a revolutionary step that affects all aspects of the design team and more CAD and architectural software developers are moving towards BIM based products. Estimating tools such as: Solibri Model Checker 8, Autodesk QTO 2012, CostX 3.5 and CATO's BIM Measure 16.4 are already available to quantity surveyors, (Cartlidge, 2013), to accelerate labour intensive ways of working for the QS (Wu et al, 2014). However, the exclusive skills needed to support the quantity surveyor e.g. following New Rules of Measurement (NRM) adopted in the UK, only BIM Measure 16.4 supports this UK-based approach to measurement automatically and additional work is needed to improve other tools (Wu et al., 2014).

BIM Adoption in the UK is a big part of construction 2025 strategy (HMGOV.UK, 2013). Government construction projects as been mandated to use BIM Level 2 from 2016 there on, from 2025 the government is expecting to move towards level 3. A key driver for this is the collaboration project with the ministry of justice, which as demonstrated an $18 \%$ saving by using collaborative working processes (HMGOV.UK, 2013). The importance of Building information modelling has begun to manifest increasingly in recent years (Mayouf et al, 2019). This has put more pressure on quantity surveyors currently in the industry to be better trained, educated and have a better understanding of BIM based products and processes. BIM adoption is heavily reliant on both existing surveyors and new graduates acquiring the skills and training to be able to implement BIM, constituting an added burden for employers and academic institutions (Mayouf et al, 2019) making some construction firms reluctant to implement it, due to cost and time implications.

BIM has been around for several years but has not be utilized to its full potential (Eadie, et al 2013), most of the use was discovered at the earlier stages of design with lesser use in the 
construction stage. This is expected to increase once BIM has a wider adoption within the industry. The benefits as backed by a survey undertaken by (Eadie et al 2013) resulted in $82.61 \%$ of people considered that BIM would be beneficial to the project against approximately $17 \%$ who thought otherwise. In summary, it can be argue that BIM seemingly has a bright and important future for the construction industry as a whole and the QS profession in particular.

\subsection{Innovations associated with related digital technologies and challenges facing Quantity Surveying practice.}

The quantity surveying profession like many others in the built environment has evolve over the years (Cartlidge, 2013). Many of the traditional services are not as vital as they once were. The development of information technology has been an integral part of this shift. Within the traditional technical role of the quantity surveyor, the main activities were limited to a narrow scope whereas within its contemporary role, QS would undertake a spectrum of work ranging from providing investment appraisals to construction project management (Thayaparan et al., 2011). As part of this reinvention and evolution, the QS has often become the clients lead consultants, thus moving up the ladder in terms of responsibility and in terms of importance within the project team (Ashworth, Hogg \& Higgs, 2013). Additional services provided by contemporary QS extends to roles in project management, lifecycle costing, value engineering and management (Smyth and Pryke, 2009). The advice given to clients has also developed, providing better detailed analysis (Davies, 2006) and as a result of past innovations, quantity surveyors have evolved into professional experts in the contractual and financial aspects of the construction management industry (Ballesty, 2007).

It has been strongly argued that innovation within the construction industry is habitually sluggish towards innovative practices (Olatunji, 2010). Challenges like wastage and costs overruns have reflected poorly on the industry and solutions to these issues are still being sought. This has supported the lack of consideration around technology in the construction industry (Sexton and Barrett, 2004). It can be claimed that computers and the development of email mode of communication has had the biggest influence on QS practices and the construction industry over the past decade. The requirement to wait for printed drawing packages and the use of scale rulers has been largely removed from the process, being replaced by emailed drawings and measurement tools for on screen take-offs. This has made the information more accessible and increased the speed of estimates and schedules, increasing clients demand. Consequently, reducing timescales for design teams to produce documents and drawings.

\subsubsection{Building Information Modelling (BIM) and the QS}

The full impact of BIM on quantity surveying is yet to be appraised (Cartlidge, 2013) but it will certainly not be the end of the quantity surveying roles. Although challenges of BIM implementation exist, the use of automatic measurement provided by current BIM software does not negate the requirement to have a professionally trained QS to verify the work as expected from a competent professional surveyor. In this regard, the Royal Institution of Chartered Surveyor (RICS) views BIM adoption as an opportunity for surveyors rather than a danger (Withers, 2019). If surveyors do not incorporate and encourage change within their respected firms, the future BIM could result in a loss of relevance of the traditional QS (Cartilage, 2013).

It has also been noted that smaller firms may be able to gain from not adopting BIM and retaining the traditional services (Cartilage, 2013). Many clients in developing countries will still benefit from more traditional QS service, if they are less concerned with speed of delivery and more concerned 
with detailed measurement and value for money. It has been pointed out that the term 'quantity surveyor' was almost redundant over a decade ago, with some QS organisations focusing instead on the proactive management of broad range of issues that affect costs and hence rebranding themselves as "cost managers" (White, 2015). Similarly, BIM Managers and BIM Coordinators are new roles in the structure of BIM which also provide new opportunities for experienced quantity surveyors. Once the UK has reached BIM Level 3 maturity, the BIM manager and coordinator roles would probably be more common due to lack of expertise within the industry but there is no indication to suggest that QS cannot play both roles, which are in fact, an opportunity for experienced quantity surveyors or commercial managers of the future.

There are some challenges when using common BIM tools in the industry in general and in spite of their great capabilities for costing and estimating, BIM tools do not eradicate the requirement for an actual estimating format (Eos Group, 2008). From such BIM tools, the quantifying data can be extracted to an MS excel spreadsheet (Eastman, 2011), and following this the QS will need to put it into their own estimating format. Furthermore, BIM models and documents do not currently have the capability to capture the 'intangibles' (site conditions, general requirements and indirect costs), or method statements (means and methods of construction) as observed by Eastman, (2011). Consequently, Sawhney, (2016) have emphasised that the QS must analyse the BIM model for accuracy and completeness, as cost estimates are only as accurate as the detailed information or data handed to the QS, which if incorrect, can lead to inaccurate information (Stanley, R and Thurnell, D, 2013). Moreover, the accuracy and quality of BIM estimates is reliant on the material specified by designers (McCuan, 2009). Other challenges that the UK construction is facing with BIM adoption is the barriers within the industry itself preventing the holistic implementation. The high cost of application, lack of national standards and lack of skilled personnel (Liu et al., 2015) are among the primary barries. Many small companies will not want to spend more for improved ICT systems and training as they currently feel it would not be worth it (Steve. R, 2014).

There are three key issues highlighted (Fig. 2) for successful BIM adoption in the UK (Khosrowshahi \& Arayici, 2012). Changes in organisation culture will be needed to make the transition to BIM Level 3 maturity. Changes in company and clerical procedures will bring improved competences. These will include alterations to technology and ICT systems including new hardware and software, changes to company structures including development of new roles for coordination, clash detection and BIM management roles are inevitable. Over time, technology will enable quantity surveyors to put together accurate estimates through BIM and other new forms of digital technology to deliver their projects. (Khosrowshahi and Arayici, 2012). Consequently, upskilling is a crucial part of the successful application of digital technology. Current staff skill levels need to improve continued professional development is important to the practices. 


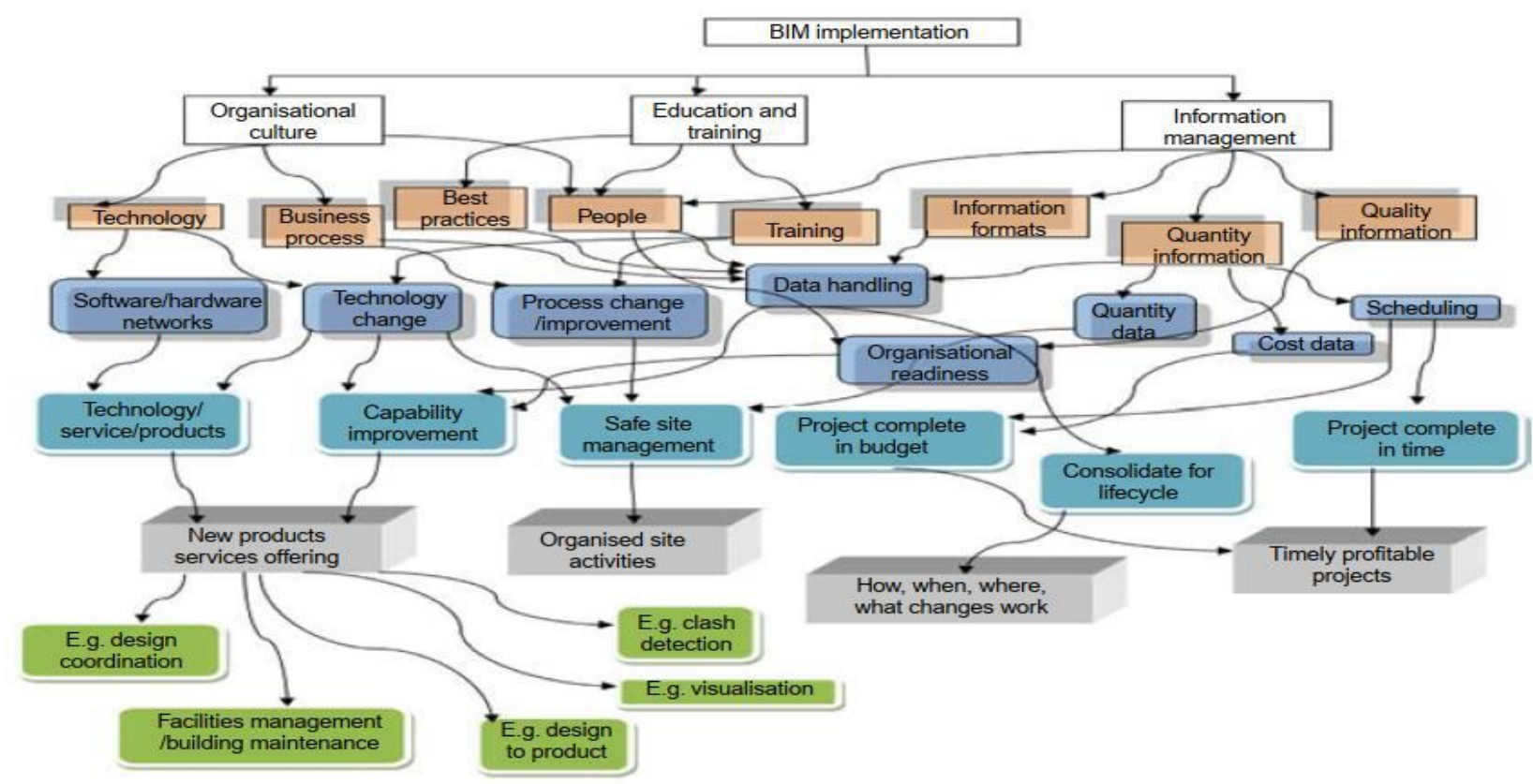

Figure 2 - BIM implementation concept map (Khosrowshahi and Arayici, 2012).

The main aim of BIM is to enhance project performance and produce better outcomes (Kjartansdottir et al., 2015) and in this regard, better performance can be attained by improving the productivity of the overall industry. Quantity surveyors and estimators are becoming more and more mindful of the improvements in quantity measurement tools used in BIM processes. Yet, it is instructive that typical digital technology-led estimating tools do not have the capabilities to compile an estimate without participation from the quantity surveyor. BIM-compliant QS tools are therefore part of a transformative process for the industry (Eastman, 2011) capable of improving the efficiency of measuring quantities and replacing the use of scale ruler to on-screen take-off. It is important, therefore, for quantity surveyors to embrace this transformation and seize the full potential of digital technology. In the current climate, there is already a lack of quantity surveyors culminating in a skills shortage. One way to elevate this is to reduce the workload of the existing quantity surveyors. With measurement becoming automatic through software, this will enable quantity surveyors to improve their services to their clients. It will negate the need to spend valuable time measuring basic construction items and increase the time quantity surveyors spend supplying advice based on detailed cost analysis, thus helping clients achieve value more efficiently.

\subsubsection{Big data and the QS}

The Most Economic Advantageous Tender (MEAT) are always considered during the tender stage of construction projects. However, there is opportunity to evaluate any tender against historical data using algorithms, which can compare and contrast large volumes of construction data and documentation. In this regard, tender evaluation can easily be enhanced with the used of Big Data (Zhang et al, 2015), with full use of previous project cost data, piloting data mining examination and providing a position for tender analysis of new or existing construction projects. The advent of $\mathrm{BD}$ is therefore making construction project cost data more realistic. The project cost data is similar to BD with the following characteristic: bulky, evolving swiftly, multi-sourced and mixed 
(Kart, 2012), and together, these provide the necessary ingredients for modern technology-driven construction cost management. Although with the presence of BCIS cost database or other form of cost data, it is uncommon to see the introduction of applicable storage and analytical technology of BD being applied on traditional databases like BCIS for guiding cost control during tender stage in construction cost management (Dean, 2008). This gap represents an important opportunity for both QS and BIM technology providers. In summary, BD technologies can support the integration of essential and wide ranging cost data needed by stakeholders for generating accurate cost estimates and social benefits, leading to higher value in the end. Other industries use big for their own value realisation and the unique value management possibilities (Bryant el at, 2008), hence the QS profession can learn from them. The technology for BD includes series of algorithms and artificial intelligence techniques, such as: Genetic algorithms, neural networks, data mining, regression analysis, clustering analysis and association rule learning, classification analysis, data integration and fusion, as well as machine learning etc. (Zhang et al, 2015). These represent some of the skills and capabilities that future QS professionals would have to acquire.

\subsubsection{Artificial intelligence and the QS}

Construction cost estimating is very important for any construction related project; it has significant effect on related activities such as: planning, design, bidding, cost and construction management (Cheng et al, 2008). Hence cost estimating is a form of cost control measure adopted by a QS in the absence of quality information during the pre-tender stage. The Quantity Surveyors would rely on historic data, past experience and knowledge in preparing an initial cost estimate. However, this reliance on human experience and knowledge has its limits (due to large numbers of variable that are inter-related with each other) and to address this challenge and improved the accuracy of construction cost estimating the potential use of computerised algorithms for estimating by QS is probably inevitable.

The use of Artificial Intelligence (AI) in the form neutral networks and regression models that improved estimating accuracy can have significant impact on decision-making in areas such as: decision on an alternative design, materials selection and cost estimating, which are all essential mainly in pre-design analysis stage (Mohamed and Celik, 1998). During the preliminary design stage, AI has been used to estimate the construction project duration and costs (Yau and Yang, 1998), including estimating highway construction cost overrun (Wilmot and Mei, 2005), and to predict variation in the construction cost index (Williams, 1994). However, for typical projects, factors, which can work against the accuracy of cost estimates, must be identify at various stages of RIBA plan of work due to the role played by the preliminary estimate prepared by the QS in helping the client to make important decision related to the success of the project (Liu and Zhu, 2007). It has been shown that the accuracy of construction cost at the feasibility stage is typically within $25 \%$ and as the project details emerge and the design evolves, this accuracy changes to $15 \%$ at the design stage with estimators input (Cheng et al, 2008). An accurate construction costs estimate will certainly help make designs decision more realistic and projects more effective by improving project management processes. With the use of AI, such reliable construction cost estimate can be provided at the preliminary stage of the project to assist with completion even with limited amount of specific project data available to the QS.

\subsubsection{Machine Learning and the QS}

Machine Learning (ML) is a branch of AI and is a method that can be used to study and mine useful cost information data, including knowledge discovery, clustering, classification, prediction, and regression (Hussain et al, 2018). Once big data has been analysed and found useful, machine 
learning techniques are employed for clustering, prediction, and classification tasks. Since the construction industry has different types of clients that are concerned with possible causes of time and cost overrun, therefore, any existing cost data and Knowledge Discovery in Databases (KDD) technique (Kim et al, 2008), can be used to extract the possible causes of cost or time overrun in an ongoing project (Soibelman and Kim, 2002). Minimising or avoiding cost and time overruns is crucial because while the client wants value for money on their projects, contractors are looking towards profit maximisation. Using ML methods, useful solutions for inaccurate cost estimation and time overrun can be found. This is plausible because the industry as a whole is in a good position of generating huge data through the various parties involved in the construction process, which can collectively be used for ML. It is arguably the lack of awareness about BD, AI and ML techniques, which prevents the construction industry from moving at a speed comparable to other industries. Although a lot of research is ongoing in this area to demonstrate the applications of $\mathrm{BD}$ and ML techniques for solving various problems (Hussain et al, 2018), it is still limited but this can be expected to change with the introduction of technology and digital tools, which need to be adopted by all stakeholders involved in construction activities.

\subsection{Methodology}

The purpose of this study is to provide a better understanding of current trajectory of BIM and digital technologies such as $\mathrm{BD}, \mathrm{AI}$ and $\mathrm{ML}$ and their potential impact on the quantity surveying profession. It is an exploratory study aimed at providing context, overview and future direction of the QS profession. The study relied solely on secondary research data compiled through literature review and findings learned from the sources. The study uses inductive reasoning (Creswell and Clark 2017) to create new knowledge as lot of the issues been investigated are hinged upon what is to transpire in the future. To use deductive resonating in this case would have proved difficult as the literature review contained many generalizations surrounding the prospect of the industry, due to its uncertainty.

\subsection{Results and Analysis.}

The research relied on studies primarily available on Google Scholar and Science Direct to discover what has been published on the issues surrounding the adoption/implementation of digital technologies (BD, AI and ML) in QS practices. The table below provides a summary of relevant research work on the subject matter. The table below shows that studies have been done on using $\mathrm{BD}, \mathrm{AI}$, and ML algorithms (typically in the context of BIM) to optimize resource planning, waste management, Tender price evaluation, Dispute and claims management, Cost estimating of building projects (pre and post), Risk management, Cost and time overrun etc.

Table 1: Studies on use of advanced technologies (BD, AI and ML) for QS related tasks

\begin{tabular}{|c|c|c|c|}
\hline Research title & $\begin{array}{l}\text { QS profession related focus of } \\
\text { the research }\end{array}$ & $\begin{array}{l}\text { Technology } \\
\text { used }\end{array}$ & Sources $(2009-2019)$ \\
\hline $\begin{array}{l}\text { Benchmarking construction } \\
\text { management performance using big data }\end{array}$ & Waste management & $\mathrm{BD}$ & Lu, et al (2015) \\
\hline $\begin{array}{l}\text { A system for tender price evaluation of } \\
\text { construction project based on big data }\end{array}$ & Tender price evaluation & $\mathrm{BD}$ & Zhang, et al. (2015) \\
\hline Use of big data in project evaluations. & Evaluation of construction projects & $\mathrm{BD}$ & Olsson and Bull-Berg (2015) \\
\hline $\begin{array}{l}\text { Prediction of outcome of construction dispute } \\
\text { claims using multilayer perceptron neural } \\
\text { network model }\end{array}$ & Dispute and claims management & $\mathrm{AI}$ & Chaphalkar, et al. (2015) \\
\hline $\begin{array}{l}\text { Hybrid use of AI techniques in developing } \\
\text { construction management tools. }\end{array}$ & Development of tools & $\mathrm{AI}$ & Ko and Cheng (2003). \\
\hline
\end{tabular}




\begin{tabular}{|c|c|c|c|}
\hline $\begin{array}{l}\text { Comparison of construction cost estimating } \\
\text { models based on regression analysis, neural } \\
\text { networks, and case-based reasoning }\end{array}$ & Cost estimating models & $\mathrm{AI}$ & Kim, et al (2004) \\
\hline $\begin{array}{l}\text { Web-based conceptual cost estimates for } \\
\text { construction projects using Evolutionary Fuzzy } \\
\text { Neural Inference Model. }\end{array}$ & Cost estimating & $\mathrm{AI}$ & Cheng, et al (2009) \\
\hline $\begin{array}{l}\text { Modelling optimal risk allocation in PPP } \\
\text { projects using artificial neural networks. }\end{array}$ & Risk management in PPP projects & $\mathrm{AI}$ & Jin and Zhang (2011) \\
\hline $\begin{array}{l}\text { Conceptual cost estimates using evolutionary } \\
\text { fuzzy hybrid neural network for projects in } \\
\text { construction industry }\end{array}$ & Conceptual cost estimating & $\mathrm{AI}$ & Cheng, et al (2010) \\
\hline $\begin{array}{l}\text { Use of artificial intelligence to predict the } \\
\text { accuracy of pre-tender building cost estimate. }\end{array}$ & Pre-tender cost estimating & $\mathrm{AI}$ & Aibinu, et al. (2011) \\
\hline $\begin{array}{l}\text { An artificial neural network approach to } \\
\text { structural cost estimation of building projects } \\
\text { in the Philippines. }\end{array}$ & & $\mathrm{AI}$ & Roxas, et al. (2014) \\
\hline $\begin{array}{l}\text { Cost premium prediction of certified green } \\
\text { buildings: A neural network approach. }\end{array}$ & Cost premium of green buildings & $\mathrm{AI}$ & Tatari and Kucukvar (2011) \\
\hline $\begin{array}{l}\text { Smart optimization for mega construction } \\
\text { projects using artificial intelligence. }\end{array}$ & Project optimisation & $\mathrm{AI}$ & Aziz, et al. (2014) \\
\hline $\begin{array}{l}\text { Potential of big visual data and building } \\
\text { information modeling for construction } \\
\text { performance analytics: An exploratory study. }\end{array}$ & Construction performance analysis & $\mathrm{BD}$ & $\begin{array}{l}\text { Han and Golparvar-Fard } \\
(2017)\end{array}$ \\
\hline $\begin{array}{l}\text { Bankruptcy prediction of construction } \\
\text { businesses: towards a big data analytics } \\
\text { approach. }\end{array}$ & $\begin{array}{l}\text { Predicting bankruptcy of } \\
\text { construction businesses }\end{array}$ & $\mathrm{BD}$ & Hafiz, et al. (2015) \\
\hline $\begin{array}{l}\text { Big data architecture for construction waste } \\
\text { analytics (CWA): A conceptual framework. }\end{array}$ & Construction waste analysis & $\mathrm{BD}$ & Bilal, et al. (2016) \\
\hline $\begin{array}{l}\text { Estimation of earthworks execution time cost } \\
\text { by means of artificial neural networks. }\end{array}$ & $\begin{array}{l}\text { Estimating earthwork execution } \\
\text { time }\end{array}$ & $\mathrm{AI}$ & Hola and Schabowicz (2010) \\
\hline $\begin{array}{l}\text { Optimized artificial intelligence models for } \\
\text { predicting project award price. }\end{array}$ & Predicting project award price & $\mathrm{AI}$ & Chou, et al. (2015) \\
\hline $\begin{array}{l}\text { Predicting construction cost overruns using } \\
\text { text mining, numerical data and ensemble } \\
\text { classifiers. }\end{array}$ & Prediction cost overruns & ML & Williams and Gong (2014) \\
\hline $\begin{array}{l}\text { Predicting construction cost and schedule } \\
\text { success using artificial neural networks } \\
\text { ensemble and support vector machines } \\
\text { classification models. }\end{array}$ & Construction cost prediction & ML & Wang, et al. (2012) \\
\hline
\end{tabular}

\subsection{Discussions and Findings}

The findings show there are clear and considerable benefits of BIM and other digital technologies such as $\mathrm{BD}, \mathrm{AI}$ and $\mathrm{ML}$ on the $\mathrm{QS}$ profession. BIM and these digital technologies face challenges in terms of adoption, tools \& software available as well as education. Although BIM is viewed as primarily about collaborative working not about the technology, the role of technology is indispensable to the process and as shown by the studies, technology can be used to perform advanced costing and estimating functions that are outside the capabilities of a human (QS). The data/evidence shows that, over the years the quantity surveying role has changed and will continue to adapt, demonstrating that it is a multipurpose and versatile profession. Although the impact of $\mathrm{BIM}, \mathrm{BD}, \mathrm{AI}$ and $\mathrm{ML}$ will require the $\mathrm{QS}$ profession to keep evolving, it has done so in the past and will continue to grow with the potential to create new roles and even retain traditional roles for the less established clientele who require it. There are improvements required, both in terms of education \& training and in terms of development of technology-driven estimating tools before they are universally accepted.

With issues surrounding cost overrun, the need for improved construction cost data has increased, and the use of big data in determining the tender price, will make this more accurate. It will have huge impact on construction cost management process with cost data mining (Zhang et al, 2015). The tender decision using technology will be reasonable and dynamic but there is need to refine and revise the algorithms to improve the result accuracy and the degree of automation of data 
mining process, which will help the clients or tenderers to analyse the tender price conveniently. The use of artificial intelligence in preparing construction cost estimate during the preliminary stage of a project will enable the stakeholder to make an accurate decision with their respective projects (Cheng et al, 2008).

\subsection{Conclusion}

A review of some of the BIM software shows that there will be some challenges quantity surveyors have to confront when using the current estimating tools. It is important that the correct one is chosen as the autonomous measuring tools to elevate the need for a quantity surveyor. The real impact of BIM on the UK market is unclear yet, but the government seem determined to implement it in their projects and advancements in digital technology tools will only speed up this process.

The potential impact of other technologies which are supplemental to BIM (e.g. big data, artificial intelligence and machine learning), will require the QS profession to adapt. However, historical evidence shows that the role has comfortably evolved from provision of traditional services to contractual and financial expertise. As it has proven so in the past, the role will continue to adapt with the potential to create new roles and even retain roles for less established clienteles, thus proving it is a versatile multipurpose profession. In terms of BIM-compliant technologies starting with the innovation in measurement tools, and inclusive of emergent tools that rely on $\mathrm{BD}, \mathrm{AI}$ and ML, quantity surveyors should become more productive as they will have more time to improve services.

In conclusion, there is little doubt that digital technologies would change the role of the quantity surveyor in the future. As technology progresses and advances there is a risk, quantity surveying practices will lag behind other professions if they do not continue to evolve and take a leading role in the direction of emergent technologies. BIM and digital technology based processes and tools will allow the quantity surveyor to investigate deeper into complex aspects of cost management procedures much further than they would have been able to with paper-based processes and drawings. The digital transformation taking place in the industry is an important opportunity for quantity surveyors and it is their responsibility to make sure they embrace collaborative working through BIM as well as the insights, power and control made possible by other technological applications. There is hope however for those unwilling to embrace the future - traditional roles of the quantity surveying may present new opportunities for the less advanced clients who are not open to (or capable of) exploiting digital technology adoption.

\subsection{References}

Ashworth, A., Hogg, K. and Higgs, C. (2013). Willis's practice and procedure for the quantity surveyor. Chichester, West Sussex: John Wiley \& Sons Inc.

Autodesk. (2019). What Is BIM | Building Information Modeling | Autodesk.com. Available at: https://www.autodesk.com/solutions/bim (Accessed 31 Mar. 2019).

Azhar, Salman, (2011). Building Information Modeling (BIM): Trends, Benefits, Risks, and Challenges for the AEC Industry. Leadership and Management in Engineering Journals, Vol. 11, Issue 3. 
Ballesty, S (2007). Building information modelling for facilities management. Australia: Co-operative research centre (CRC) for construction innovation.

Bimplus. (2019). BIM Basics: Clash detection and coordination | BIM+. Available at: http://www.bimplus.co.uk/analysis/bim-basics-clash-detection-and-coordination/ (Accessed 26 Apr. 2019).

BIM Industry Working Group. (2011), A Report for the Government Construction Client Group -Building Information Modelling (BIM) Working Party Strategy Paper, Available online at: www.bimtaskgroup.org/wp-content/uploads/2012/03/BIS-BIM-strategy-Report.pdf.

BIM Ireland. (2016). Scoping the future of BIM for quantity surveyors | BIMIreland.ie | Ireland's Only Dedicated BIM Exclusive Resource. Available at: http://www.bimireland.ie/2016/01/29/scoping-thefuture-of-bim-for-quantity-surveyors/ (Accessed 27 Apr. 2019).

Bimplus. (2019). Which countries have the highest levels of BIM adoption in Europe? | BIM+. Available at: http://www.bimplus.co.uk/people/which-country-most-bim-mature-europe/ (Accessed 24 Apr. 2019).

Bryant R, Katz, R. H., Lazowska, E. D. (2008). Big-data computing: creating revolutionary breakthroughs in commerce, science and society.

Cartlidge, D. (2013). Quantity surveyor's pocket book. 2nd ed. Abingdon, Oxon: Routledge.

Cheng, M. Y., Tsai, H. C., \& Hsieh, W. S. (2009). Web-based conceptual cost estimates for construction projects using Evolutionary Fuzzy Neural Inference Model. Automation in Construction, 18(2), 164-172.

Creswell, J. and Plano Clark, V. (2011). Designing and conducting mixed methods research.

Dakhil A, Underwood J, Al Shawi M (2019). Critical success competencies for the BIM implementation process: UK construction clients, Journal of Information Technology in Construction (ITcon), Vol. 24, pg. 80-94, http://www.itcon.org/2019/5 (Accessed 6 Apr. 2019).

Davies, R (2006). The QS Transformation. RICS Business.

Dean, J (2008). MapReduce: Simplified Data Processing on Large Clusters, Communications of the ACM - 50th anniversary issue: 1958 - 2008 Volume 51 Issue 1, 51(1): 107-113, ACM New York, NY, USA

Eadie, R., Browne, M., Odeyinka, H., McKeown, C. and McNiff, S. (2013). BIM implementation throughout the UK construction project lifecycle: An analysis. Automation in Construction, 36, pp.145-151.

Eastman, C. (2011). BIM handbook. Hoboken, New Jersey: John Wiley \& Sons.

EOS Group, (2008). Building Information Modeling: A Cost Estimating Perspective. Available at: http://cdn2.hubspot.net/hubfs/451085/pdf/BIM White Paper 6-08

no_contact.pdf?t=1509575580280 (Accessed 6 Apr. 2019).

Fung, W. P., Salleh, H., Rahim, F. A. (2014). Capability of Building Information Modeling Application in Quantity Surveying Practice. Journal of Surveying, Construction and Property, Volume 5. 
GOV.UK. (2019). Construction 2025: strategy. Available at: https://www.gov.uk/government/publications/construction-2025-strategy (Accessed 15 April. 2019).

Gu, N and London, K. (2010). Understanding and facilitating BIM adoption in the Architectural, Electrical and Construction (AEC) industry Automation in construction, Elsevie.

HM Government (2013). Construction 2025. London: Crown, pp.60-61.

Horner, R. and Talhouni, B. (2001). Effects of accelerated working, delays and disruption on labour productivity. London: Chartered Institute of Building.

Horner, M. and Duff, R. (2001). More for less. London: CIRIA.

Hussain. K, Salleh. M.M, Talpur. S and Talpur. N. (2018). Big Data and Machine Learning in Construction: A Review, International Journal of Soft Computing and Metaheuristics.

Jiang, X. (2011). Developments in Cost Estimating and Scheduling in BIM Technology. Available at: https://repository.library.northeastern.edu/files/neu:835/fulltext. (Accessed 6 Apr. 2019).

Kart, L. (2012). High-Tech Tuesday Webinar: Big Data Opportunities in Vertical Industries, Gartner, Webinar, ID No. G00236293.

Keelagher Okey Klein. (2017). QUANTITY SURVEYING - THE LOST ART OF MEASUREMENT - Available at: https://kok-surveyors.co.uk/quantity-surveying-the-lost-artof-measurement/ (Accessed 24 April. 2019).

Khosrowshahi, F. and Arayici, Y. (2012). Roadmap for implementation of BIM in the UK construction industry. Engineering, Construction and Architectural Management, 19(6), pp.610-635.

Kim, H., Soibelman, L., \& Grobler, F. (2008). Factor selection for delay analysis using knowledge discovery in databases. Automation in Construction, 17(5), 550-560.

Kjartansdottir, I., Mordue, S., Nowak, P., Phillip, D. and Snaebjorsson, J. (2015). BUILDING INFORMATION MODELLING. Construction managers library, Erasmus. Available at: https://www.ciob.org/sites/default/files/M21\%20\%20BUILDING\%20INFORMATION\%20 MODELLING\%20-\%20BIM.pdf (Accessed 15 Apr. 2019).

Kunz, J., and Gilligan, B. (2007). "Values from VDC/BIM use." Available at http://cife.stanford.edu/VDCsurvey.pdf. (Accessed March 22, 2019).

Liu, S., Xie, B., Tivendal, L. and Liu, C. (2015). Critical Barriers to BIM Implementation in the AEC Industry. International Journal of Marketing Studies, 7(6), pp.162-171. Available at: http://www.ccsenet.org/journal/index.php/ijms/article/download/55355/29675 (Accessed 6 Apr. 2019).

Liu. L, K and Zhu. K. (2007). Improving cost estimates of construction projects using phased cost factors Journal of Construction Engineering and Management, 133 (1) pp. 91-95

Mayouf, M., Gerges, M., Cox. S. (2019). 5D BIM: An investigation into the integration of quantity surveyors within the BIM process - Journal of Engineering, Design. 
McCuan, T. (2019). Cost Estimating in BIM: The Fifth Dimension. Construction Advisor Today. Available at: http://constructionadvisortoday.com/2009/11/cost-estimating-in-bim-the-fifthdimension.html (Accessed 12 Apr. 2019).

Mohamed. A, Celik. T. (1998). An integrated knowledge-based system for alternative design and materials selection and cost estimating Expert Systems with Applications, 14 (3), pp. 329-339

Olatunji, O., Sher, W. and Gu, N. (2010). Building Information Modelling and Quantity Surveying Practice. Emirates Journal for Engineering Research, 15(1), pp.67-70.

Pittard, S. (2011). Rise of the machines: BIM and QSs. Building. Available at: https://www.building.co.uk/focus/rise-of-the-machines-bim-and-qss/5019945.article (Accessed 12 Apr. 2019).

Pittard, S. and Sell, P. (2017). BIM and quantity surveying.

RIBA. (2012). BIM Overlay to the Royal Institution of British Architect. (RIBA) Outline Plan of Work. (2012). pp.3-5.

Sawhney, A. (2016). International BIM implementation guide. 1st edition. Royal Institution of Chartered Surveyor (RICS).

Sexton, M. and Barrett, P. (2004). The role of technology transfer in innovation within small construction firms. Engineering, Construction and Architectural Management, 11(5), pp.342-348.

Smyth, H. and Pryke, S. (2009). Collaborative Relationships in Construction. New York, NY: John Wiley \& Sons.

Soibelman, L., \& Kim, H. (2002). Data preparation process for construction knowledge generation through knowledge discovery in databases. Journal of Computing in Civil Engineering, 16(1), 3948.

Stanley, R. and Thurnell, D. (2013). Current and anticipated future impacts of BIM on cost modelling in Auckland. In Proceedings of the 38th Australasian Universities Building Education Association Conference, 20-22 November 2013(Auckland, New Zealand). Available at: https://unitec.researchbank.ac.nz/handle/10652/2450 (Accessed 12 April. 2019).

Thayaparan, M., Siriwardena, M., Amaratunga, D., Malalgoda, C. and Keraminiyage, K. (2011). Lifelong learning and the changing role of quantity surveying profession. Pacific association of quantity surveyors congress,15th, pp.351-360. Available at: http://www.paqs2011.lk/index.html (Accessed 11 April. 2019).

The Construction Index (2017) Construction pre-tax margins average 1.5\%, https://www.theconstructionindex.co.uk/news/view/construction-pre-tax-margins-average-15 , Accessed on 13/1/19.

White, J. (2015). BIM for QSs: Adapt or die. Building. Available at: https://www.building.co.uk/communities/bim-for-qss-adapt-or-die/5078469.article (Accessed 12 April. 2019).

Wilmot .C.G, Mei .B. (2005). Neural network modeling of highway construction costs Journal of Construction Engineering and Management, 124 (3) pp. 210-218 
Williams. T.P. (1994). Predicting changes in construction cost indexes using neural networks Journal of Construction Engineering and Management, 120 (2) pp. 306-320

Withers, I. (2019). Royal Institution of Chartered Surveyor (RICS): BIM will 'enhance QS role'. Building. Available at: https://www.building.co.uk/news/rics-bim-will-enhance-qs-role/5066168.article (Accessed 12 Apr. 2019).

Wu, S., Wood, G., Ginige, K. and Jong, S. (2014). A Technical review of BIM based cost estimating in the UK Quantity surveying practice, Standards and Tools. Journal of Information Technology in Construction (ITcon),19, pp.534-563. Available at: http://eprints.hud.ac.uk/id/eprint/22902/ (Accessed 6 April. 2019).

Yau.N.J. and Yang J.B. (1998). Case-based reasoning in construction management ComputerAided Civil and Infrastructure Engineering, 13 (2), pp. 143-150

Zhang, Y., Luo, H. and He, Y., 2015. A system for tender price evaluation of construction project based on big data. Procedia Engineering, 123, pp.606-614. 